\title{
Problems and Challenges Met by Novice Teachers in Johor
}

\author{
Tan Yoong Yee, Zainudin Bin Hassan
}

\begin{abstract}
This study aimed to investigate the problems and challenges met by novice teachers in Johor, Malaysia. This study explores the perspectives of the novice teachers on issues related to the problems and challenges and also supports in place to assist them in their transition from pre-service to in-service. Qualitative case study research method was adopted for this study. There are eight participants undergo interview session. The content of the interview was transcribed and analysed using manual analysis. The result show that novice teachers in Johor, Malaysia face challenges in aspect of self, teaching profession, students, school community, and students' parents Their biggest concern is about classroom management and students. The problems and challenges met by the novice teachers should be concerned in order to reduce problem of leaving and shortage of new teachers in teaching profession.
\end{abstract}

Keywords : problems; challenges; novice teachers; self; teaching profession, students, school community, students' parents

\section{INTRODUCTION}

The development of teacher education in Malaysia is closely related to the socio-economic and political development of the country as well as being influenced by the global trends on educational changes [13].Teacher education is under the tight control of the state as in most centralized education systems. The historical development of teacher education in Malaysia has resulted in a dual system of teacher training which involve two main type of institutions, one is administered by the Ministry of Education the other by universities. The Ministry of Education is responsible for the training of non-graduate teachers, while the universities are responsible for the training of graduate teachers [13]. On 13 July year 2005, the cabinet approved the 27 Teacher Training Colleges in Malaysia upgraded to Institute of Teacher Education (IPG). These institutions now have a mandate that entitles awarded a Bachelor of Teaching instead of just issuing institution diploma and certificate graduates. The implication of this upgrade made IPG an institution of higher education at university level. Teachers are often considered the backbone of schools. The need for well-qualified, highly competent teachers has never been greater. The certificated

Revised Manuscript Received on October15, 2019

* Correspondence Author

Tan Yoong Yee, School of Education, Faculty of Social Sciences and Humanities, Universiti Teknologi Malaysia, Malaysia. Email: amandayyt915@gmail.com

Zainudin Bin Hassan, School of Education, Faculty of Social Sciences and Humanities, Universiti Teknologi Malaysia, Malaysia. Email:

p-zainudin@utm.my teacher is the essential element in the delivery of instruction to students. Schools nationally will need to hire many new teachers to serve growing student enrolments and to replace the considerable number of teachers expected to retire. The extraordinary need for more teachers comes at time in which the demands on teachers are increasing. Schools are expected to serve an increasingly diverse population and to provide more educational and other services to students and their families than ever before.

Therefore, new teachers nowadays bring varying backgrounds, motivations, experiences, and preparation levels to their initial teaching experience. Their view of the profession and their role in it is shaped by these motivations, as well as by the context in which they begin their work [3].

\section{A. Statement of problem}

New graduates of formal teacher preparation programs frequently encounter difficulties when they experience the practical realities of schools [12]. The early years of teaching are often characterized by a "sink-or-swim" or "survival" mentality because it is often failed to provide for careful support and thoughtful development of teaching expertise over time [3]. Novice teachers enter classrooms today with high expectations for themselves and for their students. They are traditionally expected to assume all the same responsibilities as the more experienced teachers, and are often assigned the most difficult and challenging students, those that their more experienced colleagues do not want to teach [3]. Besides, new teachers are usually really eager to implement what they learned during their training program. However, they may feel that they have made a mistake choosing the teaching profession as their career when they are in schools and face unexpected situation such as classroom conditions, new educational conditions, goals, and reforms [9]. Consequently, novice teachers face many problems in terms of the emotional or physical aspects required to adapt the new situation. Thus, first year of teaching is defined as a sobering experience for most new teachers, and it causes teachers experience a decreased strength of belief in their own efficacy and in the learning potential of their students [2]. All of these will cause novice teachers to leave their chosen career even if they are really interested in the profession, and this situation will adversely affect the school and student performance. In addition, the leaving of novice teachers will also cause the shortage of teachers in schools in particular subjects. 
Nearly every study of retention in the teaching profession identifies the first three years as the riskiest on the job, which is also the years in which teachers are most likely to leave the teacher area. Therefore, the problems and challenges met by the novice teachers should be concerned in order to reduce problem of leaving and shortage of new teachers in the teaching profession.

\section{B. Objectives of the study}

The aim of this study is to;

1. To investigate whether novice teachers in Malaysia experience problems and challenges during the first three years on teaching in a school in Malaysia.

2. To investigate whether novice teachers experience problems and challenges in relation to self, teaching profession, students, school community, and students' parents.

\section{METHODOLOGY}

This study employs qualitative research method to gain the individualized perspectives and thoughts of novice teachers in Malaysia regarding the challenges faced in their first three years of teaching. This study will employ the individual unit of analysis on the selected sample population because of its' suitability for the study. It centered solely on an individual speaking for him or herself. Then, the researcher will try to understand the experience of novice teachers in their first three of teaching in school. This research uses purposive sampling method which focuses only on novice teachers in Johor, Malaysia. Besides, the sample being investigated for purposive sampling is usually quite small. Therefore, only eight respondents will be chosen to undergo this research. The sample of this study focuses on eight novice teachers who had less than five years teaching experience in school. These eight respondents will undergo interview method to have insights into this research.

This study employs the use of semi-structured interview to allow the voice of the novice teacher to inform the research. These interviews formed the basis of individual case studies. The use of case study as derived from interview in this research, aimed to serve as a powerful means for the novice teacher voice in Johor, Malaysia to be heard and to add context to challenges faced in the first three years in the profession. According to Stake [20], a case study is not a method of inquiry but rather it is one of the most common approaches to qualitative research that can be defined by the interest in an individual case. He identifies three variations of a case study as the intrinsic, the instrumental, and the collective. In essence, it is through the case studies and storied experiences of novice teachers in Malaysia that the complexity of the challenges faced at the onset to teaching can begin to be better understood.

Data collected from interview is analysed to get a conclusion of this research. The data collected will be in two forms which are hand written notes by researcher during data provided from participants, and also recorded audio voice if data from participants. The recorded audio voice of data from participants will be transformed to hard copy of print version by researcher to make the data analysis procedure to be undergone easier. Analysis of data will base on objectives and research questions of this research. The data collected was analysed using manual analysis. There are four major steps in analysing qualitative data, which are review, organize, code, and interpret. The first step is to review the data in which researcher need to review the data several times. The second step is to organize the data so that they are more manageable and easier to navigate. In this case, Figure 1 below shows some important term found inside the data.

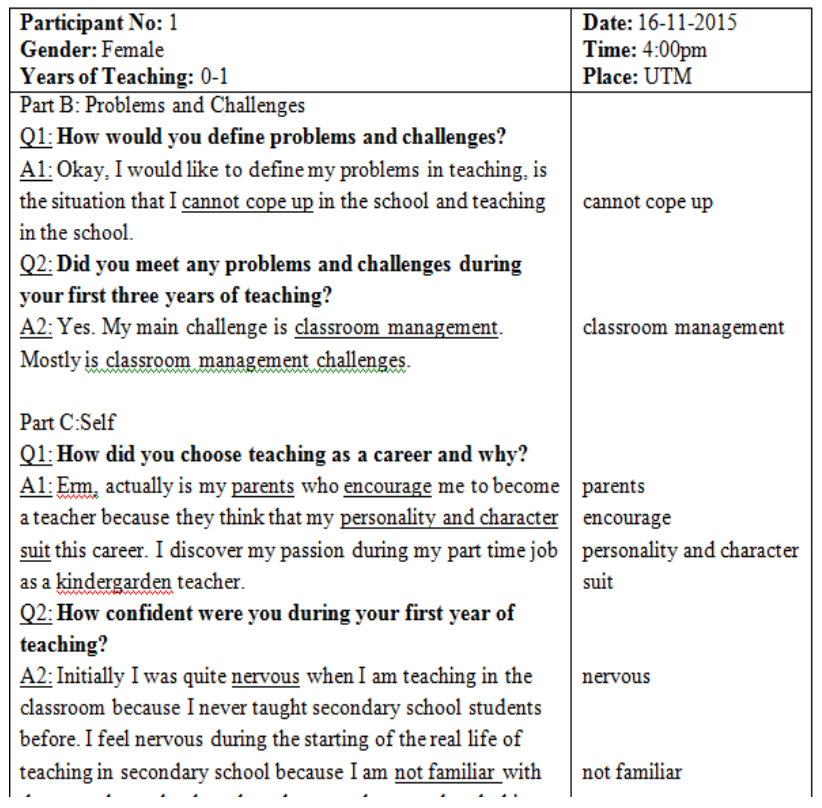

Fig. 1. Interviewing document and open coding.

There is a need to list out the important terms found in each participant' data as shown in Figure 2 below.

\begin{tabular}{|c|c|c|c|c|}
\hline $\mathrm{Chu}$ & Nurul & Siti & Teo & Lai \\
\hline $\begin{array}{l}\text { - cannot cope } \\
\text { up } \\
\text { - classroom } \\
\text { management } \\
\text { - parents } \\
\text { - encourage } \\
\text { - personality } \\
\text { and character } \\
\text { - suit } \\
\text {-nervous } \\
\text {-not familiar } \\
\text { - difficult to } \\
\text { handle } \\
\text {-not that } \\
\text { confident } \\
\text { - teacher } \\
\text { education } \\
\text { programme }\end{array}$ & $\begin{array}{l}\text { - impossible } \\
\text { to achieve } \\
\text { - no } \\
\text { experience } \\
\text { - lower } \\
\text { proficiency } \\
\text { classes } \\
\text { - difficult to } \\
\text { handle weak } \\
\text { students } \\
\text { - mis behave } \\
\text { - best for } \\
\text { female to } \\
\text { become a } \\
\text { teacher } \\
\text { - quite } \\
\text { confident } \\
\text { - students' } \\
\text { behavior }\end{array}$ & $\begin{array}{l}\text { - hard to solve } \\
\text { - need assistance } \\
\text { from others } \\
\text { - categorize the } \\
\text { students } \\
\text { - good classes } \\
\text { and bad classes } \\
\text { - follow their } \\
\text { flow } \\
\text { - design lesson } \\
\text { plan } \\
\text { - Parents } \\
\text { - Assist } \\
\text { - good future } \\
\text { - fun } \\
\text { - rural area } \\
\text { - Shaky } \\
\text { - play game } \\
\text { - get }\end{array}$ & $\begin{array}{l}\text { - can resolve } \\
\text { going beyond } \\
\text { the limit } \\
\text { - } \\
\text { effectiveness } \\
\text { of teaching } \\
\text { relationship } \\
\text { with parents } \\
\text { - temporary } \\
\text { teacher } \\
\text { - working } \\
\text { timelesser } \\
\text { - easier to } \\
\text { handle } \\
\text { children } \\
\text { - not quite } \\
\text { confident } \\
\text { - not familiar } \\
\text { teaching life }\end{array}$ & $\begin{array}{l}\text { - cannot be } \\
\text { resolved } \\
\text { - pupils' } \\
\text { attitude } \\
\text { - parent's } \\
\text { cooperation } \\
\text { - privacy of a } \\
\text { teacher } \\
\text { - remembering } \\
\text { all pupils' } \\
\text { healthy } \\
\text { condition } \\
\text { - too busy } \\
\text { - } 21^{\text {st century }} \\
\text { teaching } \\
\text { - way to get } \\
\text { all pupils } \\
\text { attention }\end{array}$ \\
\hline
\end{tabular}

Fig. 2. Open coding according to participants

Then, the third step is to code the data. Figure 3 shows the themes that had been identified after reading the data for several times. 


\begin{tabular}{|c|c|c|c|c|}
\hline \multirow{2}{*}{$\begin{array}{c}\text { Meaning of } \\
\text { Problems } \\
\text { and } \\
\text { Challenges }\end{array}$} & \multicolumn{3}{|c|}{ Issues of Problems and Challenges } & \multirow[t]{2}{*}{ Solutions } \\
\hline & Classroom & Teachers & Students & \\
\hline $\begin{array}{l}\text { - Cannot } \\
\text { cope up } \\
\text { - Difficult } \\
\text { to handle } \\
\text { - Impossible } \\
\text { to achieve } \\
\text { - hard to } \\
\text { solve } \\
\text { - need } \\
\text { assistance } \\
\text { from } \\
\text { others } \\
\text { - can } \\
\text { resolve } \\
\text { - going } \\
\text { beyond the } \\
\text { limit } \\
\text { - cannot be } \\
\text { resolved }\end{array}$ & $\begin{array}{l}\text { - Classroom } \\
\text { management } \\
\text { - Time limit } \\
\text { - Noisy } \\
\text { - Lacking of } \\
\text { school } \\
\text { facilities } \\
\text { - Good } \\
\text { classes VS } \\
\text { Weak } \\
\text { classes } \\
\text { - Lower } \\
\text { proficiency } \\
\text { classes } \\
\text { - Class } \\
\text { control } \\
\text { - changing of } \\
\text { exam } \\
\text { syllabus }\end{array}$ & $\begin{array}{l}\text { - Way of } \\
\text { teaching } \\
\text { students } \\
\text { - hard to } \\
\text { cooperate } \\
\text { - no mentor } \\
\text { - adapting } \\
\text { to the } \\
\text { busy-ness } \\
\text { of the } \\
\text { school } \\
\text { - categorize } \\
\text { the } \\
\text { students } \\
\text { - design } \\
\text { lesson plan } \\
\text { - argument } \\
\text { with } \\
\text { teachers }\end{array}$ & $\begin{array}{l}\text { - Didn't do } \\
\text { homework } \\
\text { - Discipline } \\
\text { - Naughty or } \\
\text { problemati } \\
\text { c students } \\
\text { - Weak } \\
\text { students } \\
\text { - not willing } \\
\text { to leam } \\
\text { - students } \\
\text { behavior } \\
\text { - students' } \\
\text { attitude } \\
\text { - did not } \\
\text { respect } \\
\text { teachers } \\
\text { - shy, } \\
\text { talkative. }\end{array}$ & $\begin{array}{l}\text { - discipline } \\
\text { teachers } \\
\text { - cane } \\
\text { - advise from } \\
\text { mentor } \\
\text { - leam } \\
\text { techniques of } \\
\text { effective } \\
\text { classroom } \\
\text { management } \\
\text { - receive } \\
\text { feedback } \\
\text { - different } \\
\text { approach to } \\
\text { different } \\
\text { students } \\
\text { - adapt and } \\
\text { learn from } \\
\text { real }\end{array}$ \\
\hline
\end{tabular}

Fig. 3. Open coding according to themes

The last step is to interpret the data where interpretation involves attaching meaning and significance of the data. The interpretation of data was discussed based on solving research questions.

\section{FINDINGS}

This In this section, the main objectives of this study were widely explored, and findings were made as to knowing the problems and challenges that novice teachers in Johor met.

When referring to the participants' definitions on the problems and challenges, most of the participants gives some negative ideas on their understanding on the term "problems and challenges". For instance, participants define problems and challenges as

"... the situation that I cannot cope with..." (P.1/F/0-1/S)

"... things that come in the middle of the way that make us impossible to achieve whatever we aim." (P.2/F/2-3/P)

Participants show that they actually meet classroom management problems in their first three years of teaching life.

"... my main challenge is classroom management." (P.1/F/0-1/S)

"... I have no experience in handle the classroom...the school I am posted to is a huge school....in each class there are like 40 or 50 pupils... " (P.2/F/2-3/P)

There are five participants said they choose this teacher career due to the influence of their family members especially their parents.

"...is my parents who encourage me to become a teacher because they think that my personality and character suit this career..." (P.1/F/0-1/S)

"...because my parents assist me to be the teacher.... They want me to become teacher because my sister already be teacher, my parents are teacher, and my aunty and uncle are teachers.... My parents think that this teacher career is quite a good future or me since I am a female...." (P.3/F/0-1/S)

There are some participants who gave negative opinion on their confident level in their first year of teaching, and they also tell us reason lead to it.

"...I was quite nervous... I am not familiar with the secondary school students.. I feel not that confident whether I can do a great job in this secondary school life at starting..."
(P.1/F/0-1/S)

“... shaky, because I don't know how to expect the students..." (P.3/F/0-1/S)

All the participants say that the methods and pedagogy courses that they learn did help them in teaching.

"...I think they did prepared me well... all the courses are relevant to teaching..." (P.6/F/0-1/S)

There are some participants who actually say that they met problem with students' attitude.

“... I met students who did not respect me... I am very upset... I know teachers cannot do anything like cane the students... I just tend to keep quiet and then continue my lesson calmly..." (P.6/F/0-1/S)

“... sometime the students' attitude.... They don't listen to the teachers..." (P.5/M/2-3/P)

Moreover, participants face challenges where other teachers did not agree on her type of teaching method.

“... ya... because we have many teaching methods... I like to deal with students, play with students...I like to play games, dramas, and everything... other teachers think that I do more games rather than teaching... they did not agree with my teaching method... so we have some argument there..." (P.3/F/0-1/S)

Only one participant said there are misunderstanding between parents and teacher due to some issue.

"... sometime the children will complaint to their parents saying that we say something rude... the parents will come to school and complaint... this often lead to misunderstanding between parents and teacher..." (P.4/M/2-3/P)

\section{DISCUSSION}

Novice teachers are new to the real classroom situation, and they are expected to meet problems and challenges in their first three years of teaching. First and foremost, the novice teachers' participants defined their own definition on problems and challenges. Most of the participants give negative responses on the term problems and challenges, which include cannot cope, impossible to achieve, block from proceeding, cannot be resolved, and also hard to resolve. Besides, some of them also defined that problems and challenges need to be solved with assistance from others. This question reflects back the problems and challenges the participants met in their first three years or teaching. All the participants met problems and challenges during their first three years of teaching, and some of their problems are quite similar. It can be categorized into several categories which are classroom management, busy, lesson plan, high proficiency class VS low proficiency class, parents, and students' problem. The findings above are significant with findings on challenges of novice teachers by Pelin, where students at different levels, pacing speed, workload, communicate with parents and students are the issues faced by novice teachers [17]. 


\section{A. Self}

It is necessary to know about how novice teachers chose teaching as a career and why they choose to be a teacher. Most of the novice teachers enter this field due to parents and family members. They are encouraged and inspired by their parents and family members. There are also some novice teachers become teacher due to self's interest. Cakmak's research on novice teachers' thoughts about teaching profession found that regardless of whether they started teaching profession voluntarily or not, they encountered some unexpected problems or difficulties during their first years [5]. Likewise in this research, all the participants face challenges during their first three years of teaching. Besides knowing why they step into teaching career, there is a need to know the novice teachers' feeling when they step to the real teaching life. The reason why they step into this career affect their confident level when going into the real teaching life. There are some participants who are nervous, shaky, and not confident during the first before they start teaching because they are not familiar with the school life. But there are other novice teachers who are quite confident because they are always confident for themselves. Novice teachers who is more confident possess a more positive outlook and can influence how their students perceive themselves, while novice teachers with less confident feel a sense of helplessness when it comes to dealing with difficult and unmotivated students. However, the situation changed after they start teaching. For those who are not confident at first, some of them actually increase their confident level when they feel comfortable interacting with the students. For those who are confident at first, their confidence level decreases after start teaching because the real classroom situation and teaching life is different with their expectations. Past researcher Lundeen reported that there was a distinct struggle between the processes of caring for self as a developing adult in society and caring for the needs of students in their classrooms [14]. Novice teachers believe that their confidence level relate to and will be affected by the students' attitudes and behavior, relationship with parents and school community, and many more. They also believe that confident level will be increased through experiences. This is supported by the Gu's study which found out that there was an association between the confidence level during the pre-course planning and the time spent on learning course [7].

\section{B. Teaching Profession}

Teaching profession is one of the most important elements for the novice teachers in the teaching life. There are three themes being discussed to answer this research questions. First is to investigate what is the most and least prepared for novice teachers before and when they start teaching. A study by Hammond found that there are relationships between teachers' views of their preparedness and their perception of efficacy, which linked with teacher effectiveness as well as their views of their academic preparation and their strategies to remain in teaching [8]. As for most prepared, the data is divided into three categories which are teaching content, practical, and first aid knowledge. As for least prepared, the data collected is divided into three categories also which are real school life situation, classroom management, and students' matter. Although it had practical training that brings

the novice teachers to experience real school life situation, but the limited time period for practical training did not make the novice teacher familiar with the real teaching situations. Second is to investigate the suitability of methods and pedagogy courses. All the participants agree that the methods and pedagogy courses that they learn from the teacher education programs did help them in teaching, but only for some courses. Besides, they also say that the methods and pedagogy courses did not teach them how to handle real school situations and how to control the class. This study was underpinned by Akcan in which there was more emphasis on theory rather than practice in the teacher education programs, which also suggest the need for better instruction on dealing with classroom management problem [1]. Third is to investigate the novice teachers' concern about teaching before they start teaching and after they start teaching. It is surprise to see that all the participants' concern is about their students. The difference is that they have different concern issues about their students which can divide into three categories, which are students' understanding in class, class control, and the way of teaching students.

\section{Students}

The most common term that all the participants talk about is students, thus there is a need to investigate the novice teachers in relation to students. There are three themes being considered in which are the interaction with students in the classroom, challenges deal with students, and classroom management. Classroom management is emphasized by several researchers in earlier studies [4] , [5]. All the novice teachers have their own feelings toward interaction with students; some have positive feeling, while some have negative feelings. The feeling of novice teachers when worked in the classroom is much dependent on the students' attitude and behavior. If students could behave well in the class, then teachers will work comfortably in the classroom, at the same time increase the efficiency of the teaching and learning process. The result actually agrees with Bryan's research investigating challenges new teachers met, where the biggest challenge that surfaces for new teachers is classroom management [4]. There are five main categories of challenges met by the novice teachers when deal with students in class, which are student attitude, students' interest in learning, students' behavior, homework and noisy, and time limit. There are four categories which can be formed through the responses from the participants on how novice teachers deal with the issue with students and classroom management, which are assistance from colleagues, activities, positive reinforcement, and set rules. Overall, different teachers would have different ways on solving the issues with students and classroom management, assistance from other colleagues would be important for novice teachers also. Shkedi stated that novice teachers can learn many things from experience teachers and that such interaction provides them with professional knowledge [19]. It is crucial that teachers know their students so that the planning of challenging activities is appropriate for the variety of different abilities within the learning environment.

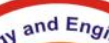
and Eng IJRTE 


\section{School Community}

School community is one of the elements that teachers will meet in their real school life. School community involves everything in school, principal, teachers, and school staff. There are three themes being considered in the relationship between novice teachers and school community, which are school procedure, policies, and organizations, challenges deal with school community, and help from school community. Most of the participants admit that they did not know about school procedure, policies, and organization when they started teaching during their first started teaching in the particular school. Besides, most of the participants did not face challenges when deal with school community. However, for the participant who did face challenges with other teachers in the school, the challenges can be divided into three categories, which are cooperation between teachers, different type of teaching methods teach, and difficult to have time interact with more experience teachers. Öztürk's study investigating the adaptation challenges of novice teachers found out that unfriendly approach of colleagues upset most of the novices [16]. Moreover, almost all the participants ask for help and receive help from colleagues in the school due to three main issues with relate to teachers, students, and projects. Some novice teachers will ask help from colleagues when they meet problems relate to students. One of the reasons is that they do not know the way to settle the student issues, and another reason is that other senior teachers will have more experience and knowledge about classroom management. Fantilli and McDougall found that some of the novice teachers who received an informal support from their peers have less challenging classroom experiences [6]. Overall it can conclude that every member in the school community is willing to help whenever the novice teachers seek for help. All teachers should know about the school procedure, policies, and organizations before they start teaching so that they will not face many challenges when dealing with school issues.

\section{E. Students' Parents}

Besides interact with students and school community, novice teachers might also need to interact with students' parents. Past researchers reported that connection with parents are one of the challenges met by novice teachers [14], [15], [10]. Thus, there are three themes about students' parents that wish to investigate which are communicate with parents, relationship with parents, and challenges in teacher-parent relationship. This study found that there are two types of situation which makes novice teachers communicate with parents from the analysis of data. First type is that the novice teachers will contact the parent whenever there are problems happened to their child even it is a normal matter, while second type is that the novice teachers will contact the parents if and only if it happened a serious issue on the children in the school. It is believed that the choice of the novice teachers to communicate with the students' parents is depends on the age and maturity level of the students. Research by Kim found that initial interactions with parents is one of the issue triggers stress for novice teachers [12]. The relationship between novice teachers and students' parents can be divided into two categories when refer to the responses given by the participants which are good, and depends on parents and situation. Some parents are open and accept what teachers told about their children, but some are not. Some students' parents could not accept the teachers to cane their child and make complaint to teachers, which indirectly break the teacher-parent relationship. Almost all of the participants opine that they did not face any challenges in teacher-parent relationship. Novice teachers did not have much pressure on the teacher-parent relationship. However, misunderstanding between teachers and parents could happen easily if there is no communication between teachers and students' parents.

\section{CONCLUSION}

As Confucius says, "a journey of a thousand miles begins with a single step." Thus, the first three years of teaching is said to be a valuable time for novice teachers to absorb and accept the new ideas in the profession [18]. It is worth to investigate what the problems and challenges they met so that the government and society will know and understand the situation the novice teachers of Malaysia met nowadays. This study aims to incorporates the voice of novice teachers and derive insight and understanding from their experiences to inform policymakers, administrators, and other major stakeholders. Novice teachers will be more inclined to stay and make a long-term contribution if they gain support from government and society after they understand the novice teachers' situation.

\section{REFERENCES}

1. Akcan, S. (2016). Novice non-native English teachers' reflections on their teacher education pro- grammes and their first years of teaching. PROFILE Issues in Teachers 'Professional Development, 18(1), 55-70. http://dx.doi.org/10.15446/ profile.v18n1.48608.

2. Bartell, C. (1995). Shaping Teacher Induction Policy in California. Teacher Education Quarterly, 22(4), 27-43. Retrieved from http://www.jstor.org/stable/23475818

3. Bartell. (2004). The Challenges Facing Beginning Teachers. 1-19.

4. Bryan, G. (2012). Research Says/ NEW Teachers Face Three Common Challenges. Supporting Beginning Teachers, 69(8), 84-85

5. Cakmak, M. (2013). Learning from teaching experiences: novice teachers' thoughts. Hacettepe Üniversitesi Eğitim Fakültesi Dergisi [Hacettepe University Journal of Education], Special issue (1), 55-67.

6. Fantilli, R. D., \& McDougall, D. E. (2009). A study of novice teachers: Challenges and supports in the first years. Teaching and Teacher Education, 25, 814-825 https://doi.org/http://dx.doi.org/10.1016/j.tate.2009.02.021

7. Gu, L., \& Papageorgiou, S. (2016). Exploring the relationships among teacher confidence, learning, and test performance within the English-for-Teaching Course(Research Report No. RR-16-24). Princeton, NJ: Educational Testing Service. http://dx.doi.org/10.1002/ets2.12110

8. Hammond, D. L., Holtzman, D.J., S.J., \& Heilig, V. (2005). Does teacher preparation matter? Evidence about teacher certification, teach for America, and teacher effectiveness. Education Policy Analysis Archives, 13.

9. Inman, D. L. M. (2004). Teacher retention: Why do beginning teachers remain in the profession? Education , 124(4), 605-614

10. Jarvis, S., \& Algozzine, B. (2006) Everything I need to know about teaching: They forgot to tell me! California, Corwin Press: Thousands Oaks.

11. Jonier, S. \& Edwards, J. (2008) Novice teachers: where are they going and why don't they stay?,Journal of Cross Disciplinary Perspectives in Education, 1(1), 36-43.

12. Kim,K. A. G. L. (2011). Novice Teachers and Their Acquisition of Work-Related Information. Current Issues in Education, 14(1). 
13. Lee, M. N. (2002) Teacher Education In Malaysia: current issues and future prospects. Teacher Education: Dilemmas and Prospects (pp.57-61). World Yearbook of Education.

14. Lundeen, C.A. (2004) Teacher development: The struggle of beginning teachers in creating moral (caring) classroom environments. Early Childhood Development and Care, 174 (6), 549-564.

15. McCann, T.M., \& Johannessen, L.R. (2004). Why do new teachers cry? The Clearing House: A Journal of Educational Strategies, Ideas and Issues, 77 (4), 138-145.

16. Oztürk, M., \& Yıldırım, A. (2013). Adaptation challenges of novice teachers. Hacettepe Üniversitesi Ĕgitim Fakültesi Dergisi [Hacettepe University Journal of Education], 28(1), 294-307.

17. Pelin, H. S. (2018). Challenges of Novice Teachers. Proceedings of ADVED 2018- 4th International Conference on Advances in Education and Social Sciences.

18. Ruzina. (2012). Job Satisfaction of new teachers in Malaysia: Understanding Challenges and Experiences of leaving the Profession. 13-14.

19. Shkedi, A. (1996). Teacher education: what we learn from experienced teachers? British Journal of In-Service Education, 22(1), 81-97.

20. Stake, R.E. (1994). Case Studies, in N.K. Denzin and Y. Lincoln (eds). Handbook of Qualitative Research. California: Sage Publications, 236-47.

21. The Alberta Teachers' Association. (2012). Retrieved from Nature of Teaching and Teaching as a Profession: http://www.teachers.ab.ca/About\%20the\%20ATA/Governance/Policya ndPositionPapers/Position\%20Papers/Pages/Nature\%20of\%20Teachin g\%20and \%20Teaching\%20as\%20a\%20Profession.aspx

\section{AUTHORS PROFILE}

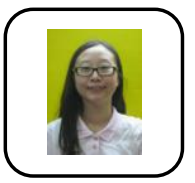

Tan Yoong Yee, School of Education, Faculty of Socia Sciences and Humanities, Universiti Teknologi Malaysia, Malaysia. Email: amandayyt915@gmail.com

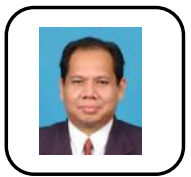

Prof. Madya Dr. Zainudin Bin Hassan

School of Education, Faculty of Social Sciences and Humanities, Universiti Teknologi Malaysia, Malaysia. Email: p-zainudin@utm.my 